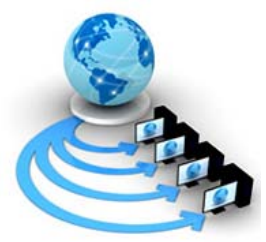

Volume 11, No. 5, September-October 2020

\title{
MODEL-BASED COURSE DESIGN FOR EFFECTIVE BLENDED LEARNING APPROACHES
}

\author{
Adekola Olubukola Daniel ${ }^{1}$ \\ Computer Science Department \\ Babcock University, Ilisan Remo, Ogun State, \\ Nigeria
}

\author{
Awodele Oludele ${ }^{2}$ \\ Computer Science Department \\ Babcock University, Ilisan Remo, Ogun State \\ Nigeria
}

\author{
Maitanmi Olusola ${ }^{3}$ \\ Computer Science Department \\ Babcock University, Ilisan Remo, Ogun State
}

Nigeria

\begin{abstract}
Blended learning has come off, more or less, as the most logical and natural evolution of our learning systems. It suggests an elegant solution to the challenges of tailoring e-learning environment to face-to-face learning environment. It represents an opportunity to integrate the innovative and technological advances offered by online learning with the interaction and participation offered in the best of traditional learning. It can be supported and enhanced by using the wisdom and one-to-one interaction of personal coaches. Believe it or not, the relevance of the pedagogy used in relaying knowledge cannot be overemphasised. Also, it has long been recognized that specialized delivery technologies can provide efficient and timely access to learning materials. A teacher handling face-to-face students might be able to discern when they are getting the message by their countenances or when they don't seem to by their reactions. How would an e-learning teacher meet the needs of their students psychologically, morally, socially and even academically since they cannot see each other? That brought the needs for the blended knowledge of ensuring that there is a predefined method of transferring idea to online students in such a way that the needs of these students are met. This is to fill such gap. This research considered the following four stages as paramount to the development and practice of blended e-learning which was adapted from IBM 4-tier: learning from information, learning from interaction, learning from collaboration, and learning from collocation.
\end{abstract}

Keywords: pedagogy, e-learning, online learning, blended learning

\section{INTRODUCTION}

The unabated debates have not stopped as to whether it is the use of a particular delivery technology or the design of the instruction that improves learning [1]. It has long been recognized that specialized delivery technologies can provide efficient and timely access to learning materials; however, [2] claimed that technologies are merely vehicles that deliver instructions, but do not in themselves influence student achievement. Research according to Clark noted that metaanalysis studies on media research have shown that students gain significantly when learning from audio-visual as opposed to conventional instruction. However, the same studies suggest that the reason for those benefits is not the medium of instruction, but the instructional strategies built into the learning materials. In the same vein, [3] suggested that learning is influenced by the content and instructional strategy in the learning materials than by the type of technology used to deliver instruction.

Blending is an art that has been practised by practical teachers for centuries. It focuses on the integration of different types of resources and activities within a range of learning environments where learners can interact, understand and build ideas. Over the past few decades, blended learning has extended learning methodologies, opening up opportunities for open and distance learning and at the same time challenging more traditional methods. Recently, the term blend has been attached to e-learning, and this blending of e-learning with traditional methods is attracting the interest of many teachers in further and higher education.

Blended learning has attracted so many definitions but found this more appealing and précised; blended learning combine face-to-face instruction with distant education delivery systems [4]. In the same manner other researchers declared that blended learning combined technology with face-to-face learning which has become generally acceptable in most research documents [5]. [6] argues that the particular attributes of the computer are needed to bring real-life models and simulations to the learner; thus, the medium does influence learning. However, it is not the computer in real sense that make students learn, but the design of the real-life models and simulations which are necessary in every online learning and the students' interaction with those models and simulations. The computer is merely the instrument that provides the processing capability and delivery medium. Kozma is correct in his claim, but learners will not learn from the simulations if the simulations are not developed 
using sound design principles in cognisance to the proposed model in Table 1.

Education has not been the driver in the use of new technologies in learning. These developments have often been driven by new trends that originated outside formal education. Electronic tools, such as DVDs, iPods, digital cameras, mobile phones and computers, are becoming ubiquitous and are very familiar to our students.

\section{OBJECTIVE OF THE STUDY}

The general objective is to determine the appropriate model that can blend the e-learning to the face-to-face methods of learning.

\section{SIGNIFICANCE OF THE STUDY}

The major significance of blended learning primarily centers on:

1. ensuring that equal benefits of face-to-face learning are available to the e-learners (along the learning curve).

2. ensuring that the same level of assessment encountered in face-to-face learning can also be acquired in the elearning environment

\section{LITERATURE REVIEW}

For the past decades, stakeholders in the education process have been seeking ways to create efficiencies and economies in the delivery of educational programs through technology-facilitated means. The appeal of low overheads and learning managed by large scale applications of technology has been a principal driving force behind much of the activity in e-learning. But more and more, the research is showing that effective learning occurs when students learn with computers rather than from computers [7]. The idea of students learning with computers describes the process where the learners' use of technology has strong teacher support whereas the notion of learning from computers suggests a setting where there is minimal evidence of teacher involvement in the actual learning processes.

[8] identifies two main models of blended learning as follows: Programme flow model: Learning activities are organized in a linear, sequential order and learners have deadlines toaccomplish the various assignments; this is similar to traditional training, but some of the activities are conducted online.

Core-and-spoke model: A major course e-learning or face-to-face (F2F) is provided and a set of supplementary materials are available to reinforce the main course; these materials are optional and not scheduled. Blended learning combines different training media such as technologies, activities and events among others to enhance optimum training programme for a specific audience. The term blended as mentioned earlier means that traditional instructor-led training is being supplemented with electronic formats in an organised manner as shown in table 1 . Moreover, e-learning reaches a wider target audience by engaging learners who have difficulty attending conventional classroom training because they are:

1. geographically dispersed with limited time and/or resources to travel;
2. busy with work or family commitments which do not allow them to attend courses on specific dates with a fixed schedule;

3. located in conflict and post-conflict areas and restricted in their mobility because of security reasons;

4. limited from participating in classroom sessions because of cultural or religious beliefs;

5. facing difficulties with real-time communication (e.g. foreign language learners or very shy learners).

6. do not have such resources in the registered school.

\section{ADVANTAGES OF E-LEARNING}

1. E-learning can offer effective instructional methods, such as practising with associated feedback, combining collaboration activities with self-paced study, personalizing learning paths based on learners' needs and using simulation among others.

2. all learners receive the same quality of instruction because there is no dependence on a specific instructor.

\section{QUALITY OF E-LEARNING}

The quality of an e-learning course is enhanced by:

1. learner-centred content: E-learning curricula should be relevant and specific to learners' needs, roles and responsibilities in professional life. Skills, knowledge and information should be provided to this end.

2. granularity: E-learning content should be segmented to facilitate assimilation of new knowledge and to allow flexible scheduling of time for learning.

3. engaging content: Instructional methods and techniques should be used creatively to develop an engaging and motivating learning experience.

4. interactivity: Frequent learner interaction is needed to sustain attention and promote learning.

5. personalization: Self-paced courses should be customizable to reflect learners' interests and needs; in instructor-led courses, tutors and facilitators should be able to follow the learners' progress and performance individually.

\section{RELATED PAPERS}

Since blended learning and its implementation is relatively new subject in higher education institutions, there is limited number of published researches dealing solely with blended learning environments in teacher education. It is also acknowledged by [9] that there is limited number of research work online on blended learning in teacher education specifically when it is compared to the research on the practice and theory of blended learning in other disciplines.

However, there are plenty of studies in the literature that dealt with implementation of Web-based instruction into campus based instruction and there are a growing number of faculties experimenting the innovative technology mediated approaches to teaching, such as the use of tools for simulations, visualization, communication, and feedback that are transforming the ways that students learn [10].

The available literature on the studies dealing with blended learning and its implementation in different contexts revealed that most of the studies dealt with theoretical 
grounds of blended learning implications in corporate environments. Among the studies dealing with implementation of Web-based instruction into facet of ace instruction were carried out by [11];[12]. In his study, Sze aimed at making peer observation more accessible, flexible, and user-friendly, which would not be possible in a traditional, school-based setting. In [11] study, the researchers piloted a study that examined perceptions of Early Childhood Education student teachers towards elearning.

\section{BOTTLENECK OF FULL IMPLEMENTATION OF E-LEARNING IN DEVELOPING COUNTRIES}

Challenges battling full implementation of e-learning in developing countries include students' technical limitations such as bandwidth, computer hardware and so on. Poor technical infrastructure on the part of students can impede course activities. For example if a student does not have appropriate facility to enjoy what he/she should learn through a site with heavy content such as some graphics or video contents. Secondly, instructors need technical and pedagogical training to meet with the need of e-learning. Elearning instruction differs fundamentally from traditional approaches and requires a major commitment of time and training. Knowledge at the other end cannot also be overlooked i.e. many students are computer savvy but not necessarily computer literate. That is, they do well with computers to do their pleasure for example playing games but not so well in using it for learning. Furthermore, course preparation might require learning a new software application to convey a concept more effectively. Faculty spends substantial time and effort reengineering the course to adapt it for online delivery. This means a significant amount of extra effort for instructors. Students having to express their learning efforts via video, audio, text creates new challenges that students and instructors must deal with.

Lack of quality assessment and feedback as well as inadequate or sometimes lack of mentorship which hinders learning.

Digital literacy issue and digital divide (i.e. only some groups or locations have access to this technology) directly affects growth in e-learning direction.

TABLE I Blended Model table and Analysis. Source: IBM 4-Tier Model

\begin{tabular}{|c|c|c|c|c|c|}
\hline $\mathbf{S} / \mathbf{N}$ & Tiers & Meaning & Process & Technologies & Category \\
\hline 1 & $\begin{array}{l}\text { Learning from } \\
\text { Information }\end{array}$ & $\begin{array}{l}\text { Performance support } \\
\text { and reference materials }\end{array}$ & $\begin{array}{l}\text { Read it, watch it, listen to } \\
\text { it, be directed by it. }\end{array}$ & $\begin{array}{l}\text { Websites, audio seminars, } \\
\text { videos, books, e-books }\end{array}$ & Internet \\
\hline 2 & $\begin{array}{l}\text { Learning from } \\
\text { Interaction }\end{array}$ & $\begin{array}{l}\text { Interactive learning. } \\
\text { Games and simulation }\end{array}$ & $\begin{array}{l}\text { Examine it, try it, play at } \\
\text { it, interact with it }\end{array}$ & $\begin{array}{l}\text { CBT/WBT modules, } \\
\text { interactive games, multimedia } \\
\text { or actual simulation }\end{array}$ & Multimedia \\
\hline 3 & $\begin{array}{l}\text { Learning from } \\
\text { collaboration }\end{array}$ & Collaborative learning & $\begin{array}{l}\text { Discuss it, practice it with } \\
\text { others, create virtual } \\
\text { communities of practice or } \\
\text { purpose }\end{array}$ & $\begin{array}{l}\text { Live Virtual classrooms, e- } \\
\text { labs, e-Teams Collaborative } \\
\text { Sessions, Web Conferences }\end{array}$ & Collaborative \\
\hline 4 & $\begin{array}{l}\text { Learning from } \\
\text { Collocation }\end{array}$ & $\begin{array}{l}\text { Experienced Based } \\
\text { Learning }\end{array}$ & $\begin{array}{l}\text { Getting together, Meet as } \\
\text { a community, Develop } \\
\text { relationships, Live it, Do } \\
\text { it. }\end{array}$ & $\begin{array}{l}\text { Mentoring, Role Playing, } \\
\text { Case Studies, Coaching }\end{array}$ & Face-To-Face \\
\hline
\end{tabular}

\section{CONCLUSION}

The blended concept has emerged a leading approach to learning due to the fact that it has successfully combined the best of the worlds of face-to-face and e-learning and then consequently given birth to a wholesome learning systems. Should face-to-face or e-learning method to ride independently alone, each, on its own, will trudge along with their respective flip sides or flaws. For face-to-face, part of what learners can suffer is inability to survive with the trend and speed of technological breakthrough of the century we belong. On the part of strictly e-learning, capturing the response, reaction, emotion and meeting other psychological needs of the students which could aid their learning could be pretty difficult. And of what use is a learning process that cannot deliver the message or gain complete accomplishment with the learners. Blended learning is a bridge that was put forward to resolve the imbalance. Here, innovative gain of elearning is optimized and interaction and participation offered best only in traditional learning setting is explored. This paper also acknowledged stages as paramount to the development and practice of blended e-learning.

\section{REFERENCES}

[1] Clark, R. (2001). Learning from Media: Arguments, Analysis, and Evidence. Greenwich, Connecticut: Information Age Publishing

[2] Clark, R. E. (1983). Reconsidering Research on Learning from Media. Review of Educational Research, 53(4), 445-459.

[3] Schramm, W. (1977). Big media, little media. Beverly Hills, CA: Sage.

[4] Osuguthorpe.R.T and Graham, C.R. (2003). Blended learning environments: Definitions and directions. The Quarterly Review of Distance Education 4(3). 227-233

[5] Bonk, C. J., \& Reynolds, T. H. (1997). Learner-centered web instruction for higher-order thinking, teamwork, and apprenticeship. In B. H. Khan (Ed.), Web-based instruction (pp. 167-178). Englewood Cliffs, NJ: Educational Technology Publications.

[6] Kozma, R. B. (2001). Counterpoint theory of 'learning with media'. In R. E. Clark (Ed.), Learning from media: Arguments, analysis, and evidence (pp. 137-178). Greenwich, CT: Information Age Publishing Inc.

[7] Collis, B., \& Moonen, J. (2001). Flexible learning in a digital world: Experiences and expectations. London: Kogan Page.

[8] Bersin, J. (2004). The blended learning book: Best practices, proven methodologies, and les-sons learned. New York, NY: John Wiley \& Sons

[9] Young, A., \& Lewis, C. W. (2008). Teacher education programmes delivered at adistance: An examination of 
distance student perceptions. Teaching and Teacher Education, 24(3), 601-609

[10] West, R. E., \& Graham, C. R. (2005). Five powerful ways technology can enhanceteaching and learning in higher education.Educational Technology, 45(3), 20-27

[11] Sze, P. M. (2006). An online peer observation platform for English language teachers in Hong Kong. Paper presented at
Processes and Process- Orientation in Foreign Language Teaching and Learning (CLASIC 2006), December 7- 9, 2007,Singapore.

[12] Holstrom, L., Ruiz, D., \& Weller, G. (2007). A new view: Reflection and student teacher growth through an e-practicum model E-Learning, 4(1), 5-14. 